\title{
THE IMPLIED ETHICS OF THE FOURTH GOSPEL: \\ A REINTERPRETATION OF THE DECALOGUE
}

\author{
Jey J. Kanagaraj
}

\begin{abstract}
Summary
Despite the lack of explicit and detailed ethical teachings in the Fourth Gospel, it seems that the Jewish ethics embodied in the Decalogue undergird John's presentation of the Gospel. The words 'keep my commandments', used by Jesus in the Fourth Gospel, give us the key for understanding the implied ethics of the Fourth Gospel. An analysis of John's Gospel shows that its author reflects the Decalogue in various parts of the Gospel. We have evidence that John reinterprets the commandments positively and redemptively by focussing on Jesus as the one who fulfils the commandments and who enables those who believe in him to fulfil them. Such an interpretation of Yahweh's commandments, which can be identified as Jesus' commandments in the Gospel, cannot simply be dismissed as accidental but rather reflects a conscious reinterpretation of the Law.
\end{abstract}

\section{Introduction}

John's Gospel has been an enigma to the ethicists who seek to find moral teachings in it. Donald Guthrie, who includes a section on personal ethics in John's Gospel in his New Testament Theology, affirms at the outset that this Gospel is not strong on explicit ethical teaching, because, for him, it has more to say about believing than doing. ${ }^{1}$ J.T. Sanders, who affirms that Johannine Christianity is interested only in whether one believes, envisages the 'weakness and moral bankruptcy of the Johannine ethics' in today's context in which Christian groups that are interested only in one's own salvation still exist. ${ }^{2}$ For E.E.

1 D. Guthrie, New Testament Theology (Leicester: IVP, reprint, 1985), p. 907.

2 J.T. Sanders, Ethics in the New Testament: Change and Development (Philadelphia: Fortress, 1975), pp. 99-100; W.A. Meeks, 'The Ethics of the Fourth 
James, John's main concern is the doctrine of salvation and not ethics. ${ }^{3}$ W. Marxsen observes that ethics in the Gospel of John in terms of specific instructions and admonitions are completely absent except one single ethical term 'love'. ${ }^{4}$ Richard B. Hays, who does recognise the moral vision of the Johannine Church and the ethical implications of its eschatology, claims that the love command plays a central role in the ethical teaching of Johannine literature, even while he points out that for readers seeking ethical themes, the Gospel of John is a puzzling text. ${ }^{5}$ The list could go on.

The relatively negative view of many such scholars on Johannine ethics is due to the absence of any explicit moral teachings such as Matthew, for example, has in the Sermon on the Mount. There is no reference in John to the question of marriage and divorce nor to that of paying taxes to the government. There is no mention of forgiving the sins of one's brother (or sister) nor does the Gospel include the parable of the Good Samaritan. John does not record any of Jesus' sayings on subjects such as defilement of the human heart by means of what goes out of it or the need for repentance. In spite of the importance given in John to individual characters, there is no reference to the injunction given to an individual like the rich young ruler to give his possessions to the poor nor is there any reference to an individual like Zacchaeus who, after his meeting with Jesus, divulged his desire to give away half of his goods for the welfare of the poor.

At the same time, those who belittle the ethical demands of the Fourth Gospel ignore the fact that 'believing' for John is not a static phenomenon but a productive action performed in the world in union with Christ. ${ }^{6}$ They also ignore that the gift of salvation given by the Father and the Son carries with it a sense of responsibility for the believing community in terms of abiding in him and yielding fruit to the society in which they live. Even Hays seems not to appreciate this

Evangelist', in Exploring the Gospel of John (FS D. Moody Smith; eds R.A. Culpepper \& C.C. Black; Louisville: Westminster John Knox, 1996), pp. 317-26.

3 E.E. James, Ethics: A Biblical Perspective (Bangalore: Theological Book Trust, 1992), p. 121.

4 W. Marxsen, New Testament Foundations for Christian Ethics (ET; Edinburgh: T. \& T. Clark, 1993; originally published 1989), p. 286.

5 R.B. Hays, The Moral Vision of the New Testament: Community, Cross, New Creation: A Contemporary Introduction to New Testament Ethics (San Francisco: Harper, 1996), pp. 138-57.

6 See C. Koester, 'Hearing, Seeing, and Believing in the Gospel of John', Biblica 70 (1989), 327-48 for the correlation that exists between 'seeing', which is preceded by 'hearing', and 'believing'. We should add that 'believing' eventually leads to 'witnessing' (Jn. 1:14, 34; 19:35). Cf. below pp. 58-59. 
point in his discussion of 'the Paraclete' who, for him, is merely a source of comfort and an aspect of eternal life within the community.? Hays is surely right that Sanders's harsh verdict on the ethical quality of John's Gospel is hasty, neglecting the historical context of John and its understanding of the world in which the Christian community is set to live. ${ }^{8}$ However, Hays' study itself, on the whole, does not offer as much insight into the ethical values embedded in the Fourth Gospel as one would expect in a such a work. It is worthwhile, therefore, to pose the questions: does the Gospel of John reflect the ethical values that are insisted on in other parts of the New Testament? Apart from the love command, did the Fourth Gospel seek to make any other moral impact on its first readers?' ${ }^{9}$ Is the Gospel 'ethically deficient', as many scholars hold, or is it ethically more enriching than is normally thought? Answers to these questions call for a closer study of the Gospel of John.

\section{Commandment and Commandments}

An important aspect which can possibly throw further light on Johannine ethics and which hitherto has remained unexplored is John's use of the words $\dot{\varepsilon} v \tau 0 \lambda \dot{\eta}$ and its plural $\dot{\varepsilon} v \tau 0 \lambda \alpha$ í. The singular $\varepsilon \dot{\varepsilon} v \tau \lambda \eta \dot{n}$ appears six times in John $(10: 18 ; 11: 57 ; 12: 49,50 ; 13: 34$; $15: 12)$, once being used without any theological significance

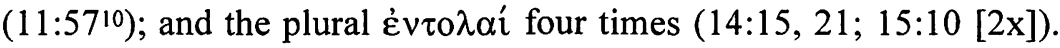
The verb $\dot{\varepsilon} v \tau \varepsilon \dot{\varepsilon} \lambda \lambda \circ \mu \alpha \imath$ is also used three times $(14: 31 ; 15: 14,17) .{ }^{11}$ Commentators have taken different views on the significance of these words. Some have taken it for granted that there is no specific variation in the meaning of singular and plural forms of $\dot{\varepsilon} v \tau 0 \lambda \eta$, whereas others have pointed out the significance of each word.

\footnotetext{
7 Hays, Moral Vision, pp. 150-52.

8 Hays, Moral Vision, p. 140.

9 For a recent study emphasising the positive role of the love command within Johannine ethics see J. Nissen, 'Community and Ethics in the Gospel of John', in New Readings in John: Literary and Theological Perspectives (ed. J. Nissen \& S. Pedersen; JSNTS 182; Sheffield: Sheffield Academic, 1999), pp. 194-212.

10 The proto-Alexandrian MSS ( $N \mathrm{~B}$ ), the pre-Caesarean MS (W) and some minuscules have $\dot{\varepsilon} v \tau 0 \lambda \alpha \dot{\alpha}$. The singular $\dot{\varepsilon} v \tau 0 \lambda \eta \dot{\eta} v$ is supported by a wide range of early and reliable manuscripts $\left(P^{66}\right.$ A D L $\Theta \mathrm{f}^{13}$ etc.). R.E. Brown comments, 'There is respectable evidence for reading the singular.' The Gospel According to John I-XII [AB 29; New York: Doubleday, 1966], p. 445. However, the meaning is not very different in this context.

11 Excluding as secondary the occurrence in $\mathrm{Jn}$. 8:5.
} 
Bultmann, for example, argues that there is no obvious difference between $\dot{\varepsilon} v \tau 0 \lambda \dot{\eta}$ and $\dot{\varepsilon} v \tau 0 \lambda \alpha^{\prime}$, as they are used interchangeably in 1 John 2:3-5; 2:7-8; and 3:22-23. He comments that 'his commandments' in 15:10 indicates only one commandment, the commandment of love. ${ }^{12}$ Brown, who finds a variation in the meaning of singular and plural, maintains that Jesus' commandments are not simply moral precepts, but that 'they involve a whole way of life in loving union with him'. ${ }^{13}$ In similar vein, Beasley-Murray comments that the interchange of 'my commands' in 14:15 with 'my word' and 'my words' in 14:21, 23, 24 suggests that év full range of the revelation from the Father than simply ethical instructions. ${ }^{14}$ However, Carson brings out the distinction clearly, and in my view rightly, by saying that the plural form probably focuses on the 'individual components of Jesus' requirements', while the singular, in conformity with the term 'word', focuses on the 'Christrevelation as a comprehensive whole'.15 A similar view was

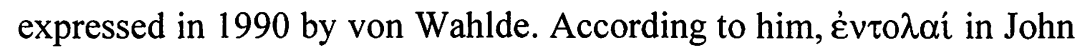
14 and 15 refers to general exhortation, implying particularly the individual elements of the 'law', whereas the singular $\dot{\varepsilon} v \tau o \lambda \dot{n}$ indicates a specific commandment. ${ }^{16}$ But the question arises: what are the individual elements of ethics referred to in John?

The first Christians treated love as the summary of the Law (Rom. 13:8-10), the root of which, they rightly believed, goes back to Jesus himself (Mt. 22:35-40; Mk. 12:28-34; Lk. 10:26-28; cf. Lv. 18:5; 19:18). When they treated love for one's neighbour as fulfilment of the Law, they often understood 'Law' as pointing to the Decalogue (Rom. 13:9-10). ${ }^{17}$ A devout Jew would think of the Decalogue and

12 R. Bultmann, The Gospel of John: A Commentary (Philadelphia: The Westminster Press, ET 1971), p. 541. Similarly R. Schnackenburg, The Gospel According to St. John, Vol. III (New York: Crossroad, 1990), p. 103, thinks that the plural 'commandments' in 15:10 is specifically defined as the commandment of brotherly love. However, Bultmann comments that this meaning is not

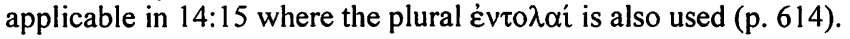

13 R.E. Brown, The Gospel According to John XIII-XXI (AB, 29A; New York: Doubleday, 1970), p. 638.

14 G.R. Beasley-Murray, John (WBC, 36; Dallas: Word Books, 1987), p. 256.

15 D.A. Carson, The Gospel According to John (Leicester: IVP; Grand Rapids: Eerdmans, 1991), p. 498.

16 Urban C. von Wahlde, The Johannine Commandments: 1 John and the Struggle for the Johannine Tradition (New York: Paulist Press, 1990), pp. 21-25, 32-33.

17 Paul's citation of the seventh, sixth, eighth, and tenth commandments in Rom. 13:9 (some manuscripts add the ninth commandment as well) in fact stands for the whole Decalogue. Only these commandments are cited here mainly to emphasise love for one's neighbour. 
other related moral precepts as fundamental to covenantal Judaism and the rendering of the love command in such negative as well as positive form is characteristically Jewish. ${ }^{18}$ It is highly probable that John, like Paul, was brought up in such a tradition and that behind his doctrine of love stands the Decalogue..$^{19}$ Could John, then, have placed the Decalogue at least as the backdrop when he set the love command in the forefront? If yes, in what sense does he reflect the Ten Commandments themselves? Answers for these questions deserve to be explored in the Fourth Gospel whose ethics are expressed most clearly in relation to the love command.

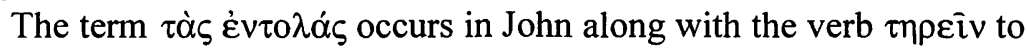
imply obedience as the expression of one's love for Jesus $(14: 10,15,21 ; 15: 12)$. The same expression is used for 'keeping' the Ten Commandments (cf. Mt. 19:17-19; 1 Cor. 7:19) ${ }^{20}$ and the

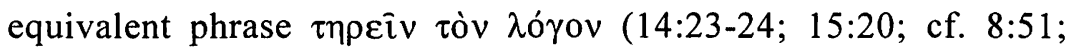
$1 \mathrm{Jn} .2: 5)$ alludes to Exodus 20:1 and Deuteronomy 5:22 where the

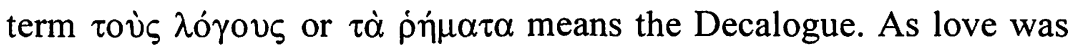
treated as the summary of the Law, particularly in Christian circles, both Jews and Christians had acknowledged the Decalogue as the 'content of the Law'. ${ }^{21}$ This means that in the first century both love and the Decalogue were treated in complementary and identical terms.

My proposal in this essay is that John, who emphasises the love command, shows at the same time clear traces of the influence of the Decalogue in his Gospel and that this in turn influences and informs his ethical teachings. However, this does not mean that the Fourth Gospel has a coherent and systematic use of the Decalogue. But we can notice several allusions to the individual commandments of the Decalogue which betray John's ethical stand. As a Jew, the author of the Fourth Gospel was influenced by the Decalogue in his writing. As

18 See J.D.G. Dunn, Romans 9-16 (WBC 38B; Waco: Word, 1991), pp. 778, 782.

19 For the connecting ideas between Paul and John, see C.K. Barrett, The Gospel According to St. John (Philadelphia: Westminster, 2 ed., 1978), pp. 54-59; Bultmann, John, pp. 9-10.

20 See J.H. Bernard, A Critical and Exegetical Commentary on the Gospel According to St John, II (ICC; Edinburgh: T. \& T. Clark, repr. 1949), p. 545; Brown, John XIII-XXI, p. 638; von Wahlde, Johannine Commandments, pp. 25-26.

21 See R.S. Wallace, The Ten Commandments: A Study of Ethical Freedom (Edinburgh/London: Oliver and Boyd, 1965), p. 1. James Bergquist points out, 'The commandments stand as the essential-but not the exhaustive- summary of how God wants his people to live in both their individual and their community relationships.' J. Bergquist, The Ten Commandments and Responsible Freedom (Madras: CLS/Delhi: SPCK, 1971), p. 16. Cf. also von Wahlde, Johannine Commandments, p. 9. 
our study shows, his positive approach to the Ten Commandments and his reinterpretation of them with a strong emphasis on love can hardly be treated as accidental, but rather reflects the impact of his encounter with Christ.

\section{Influence of the Decalogue on Johannine Thought}

For the sake of clarity we shall take up each commandment of the Decalogue in turn for our analysis. But before doing that, a preliminary remark needs to be made. The setting of the Decalogue (or ten words-Ex. 34:28b; Dt. 4:13; 10:4) is the state of freedom attained by the Israelites from Egyptian slavery. The terminology of freedom, which is not found in Synoptic Gospels, has an important place in John's Gospel particularly in the account of Jesus' dispute with the Jews (8:21-59). The statement, 'The truth will make you free' (8:32), triggers the debate between Jesus and the Jews. Jesus mentions that humans are by nature slaves to $\sin (8: 34)$ and that he offers freedom from $\sin (8: 36)$, for he, being himself sinless, has removed sin by his death and resurrection $(8: 46 ; 1: 29,36$; cf. 16:8). Ironically the verbal form of the word $\delta o v \lambda \varepsilon i \alpha$ that is used in Exodus 20:2 LXX is put in the mouth of the Jews who claim that they are descendants of Abraham and that they have never been in bondage to anyone (8:33). This will remind any Jewish reader of the exodus tradition, especially the bondage in which the forefathers lived, the freedom they obtained, and the commandments they received as a mark of Yahweh's covenant with them.

\section{The First Commandment}

'You shall have no other gods before me' (Ex. 20:3)

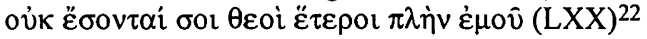

According to G. von Rad, this commandment is 'the commandment par excellence for Israel' ${ }^{23}$ Philo treats it as 'the first and most sacred of commandments, to acknowledge and honour one God who is above

22 There are four different methods of enumerating the Decalogue (Josephus/ Philo, Catholic/Lutheran, Reformed, and Jewish), as shown by E. Nielsen, The Ten Commandments in New Perspective (London: SCM, 1968), p. 10. I follow the enumeration of what he calls the 'Reformed Church', as this follows MT. This way of counting is followed today by Anglican and other related traditions.

23 G. von Rad, Deuteronomy. A Commentary (ET; London: SCM, 1966), p. 56; quoted by J.J. Stamm and M.E. Andrew, The Ten Commandments in Recent Research (ET; SBT 2.2; London: SCM, 1967), p. 81. 


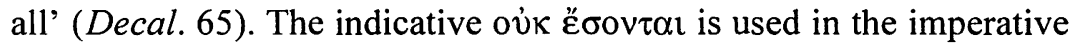

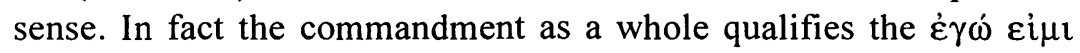
statement found in the preceding verse. In the light of God's sole claim for his own glory and of his act of deliverance from slavery, the first commandment calls people for a special relationship with Yahweh by committing themselves to him alone. The idea of exclusive devotion to Yahweh makes the monotheistic interpretation of this commandment possible. ${ }^{24} \mathrm{~A}$ single-minded attitude towards Yahweh, within the context of a real temptation to follow 'other gods', is demanded.

Among the four evangelists, John alone plainly confesses God as o

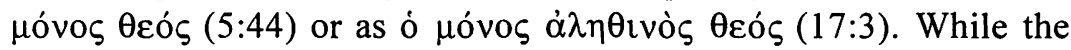
word $\dot{\alpha} \lambda \eta \theta$ vvó $\varsigma$ echoes the Exodus tradition (Ex. 34:6), the word $\mu$ óvo $\varsigma$ echoes not only the Isaianic tradition (e.g. Is. 37:20), but also Yahweh's exclusive claim in Ex. 20:1. Such claims were used in opposition to the polytheism of the Gentile world in the late first century, ${ }^{25}$ a situation similar to the time when the Decalogue was given. By stating the content of eternal life as knowing the only true God and Jesus Christ, John implies that the only true God was revealed to human beings in and through Jesus and that a person who does not confess Jesus does not confess the only God who sent him. ${ }^{26}$ Thus John shows a deep concern for human relationship with the only true God, Yahweh, who made himself known in his Son (1:18). This

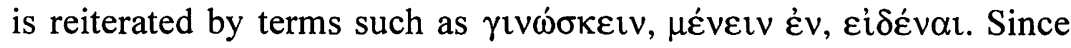
both God and Jesus are one (10:30) and since both exist in one another $(14: 10-11,23 ; 17: 21,23)$, it is impossible to recognise the only God without recognising Jesus and it is impossible to relate to him without relating to Jesus $(8: 19,28)$. Jesus is the incarnation of the Logos, who was eternally existing with God in inseparable communion with him (1:1). John brings out the idea of human relationship with God precisely in the framework of monotheism. The theme that the one God was revealed to human beings through his

24 J.M. Lochman, Signposts to Freedom: The Ten Commandments and Christian Ethics (ET; Minneapolis: Augsburg, 1982), pp. 35-36, argues that this commandment in its original context does not necessarily imply the acceptance of monotheism in principle. Similarly J.I. Durham, Exodus (WBC 3; Waco, Texas: Word, 1987), p. 285. However, Lochman agrees that the exclusive devotion to Yahweh implied by the first commandment served to nurture OT monotheism. Viewed in the context of v. 2, monotheism is at the forefront.

25 Cf. Brown, John XIII-XXI, p. 741.

26 Ibid., p. 752. 
Son, Jesus Christ, runs throughout the Gospel. ${ }^{27}$ God's unique claim of the name 'I AM' (Gn. 15:1; 28:13; Ex. 3:14; Is. 41:4; 42:8; $43: 10,11,25 ; 44: 6 ; 45: 18 ; 48: 12 ; 51: 12 ; 52: 6$; Ho. 13:4; Joel 2:27; etc.), in the midst of the false claims made by unknown gods, is applied in John's Gospel to Jesus who delivers people from the bondage of sin (8:31-36). By taking the name of God 'I AM' upon himself, the Johannine Jesus affirms that he is the very presence and activity of God among people in creation and salvation and that he is the revelation of the God of the OT.28

Unlike the first commandment, John does not use a negative prohibition, 'You shall have no other gods'. But he brings out the meaning of this commandment positively by focussing on Jesus who is not only the revelation of God to human beings, but also the unique means by which one can relate to him. For John a faith commitment to the God who was revealed in the Logos incarnate is fundamental to ethics. It is the relationship between Jesus and believers that is 'determinative for the community's ethical norms' ${ }^{29}$ John presents the first commandment more positively because of the grace initiated by God to reveal himself in human language. He thus sets divine Law that demands moral behaviour from humans in conjunction with divine grace and communion that are available in Jesus to fulfil that demand. John's presentation of a christology which does not lose sight of monotheism suggests that the author of the Gospel was a Jewish Christian whose experience of Christ enabled him to understand the Law in a new and practical manner.

27 As emphasised in R. Bultmann, John: A Commentary (although Bultmann understands the Johannine Jesus as the Revealer against the background of gnostic revealer, his overall thesis that Jesus reveals the one true God is well-taken). Cf. also G.R. O'Day, Revelation in the Fourth Gospel (Philadelphia: Fortress, 1986).

28 God's first utterance in creation ' 'אהיה ('Let it be...') or/will be...'), as God's Logos, emphasises God's presence/activity among people; C.T.R. Hayward, 'The Holy Name of the God of Moses and the Prologue of St. John's Gospel', NTS 25 (1979), 16-32, esp. 28-29. This idea can be identified with John's use of the name of God, 'I AM'. Jesus' claim 'I AM', if viewed against an Isaianic background, can be understood as the God who saves and forgives; and by this claim Jesus claims for himself the words as well as the nature of God in a religious context of several claims for divinity by foreign gods; see D. Ball, "I am...": The "I am" Sayings of Jesus and Religious Pluralism', in A.D. Clarke and B.W. Winter (eds.), One God, One Lord: Christianity in a World of Religious Pluralism (Grand Rapids: Baker, 1992), pp. 65-84. Cf. C.H. Dodd, The Interpretation of the Fourth Gospel (CUP, 1954), pp. 93-96 for rabbinic evidence of God's Name as 'I AM'.

29 Hays, Moral Vision, pp. 142-43. Hays demonstrates that Johannine ethics are based on an incarnational Christology which pictures Jesus as the one in whom creation and redemption are held together and in union with whom the community of believers will reflect his very life and mission. 


\section{The Second Commandment}

'You shall not make for yourself a graven image, or any likeness ... you shall not bow down to them or serve them; for I the Lord your God am a jealous God, ... showing steadfast love to thousands of those who love me and keep my commandments.' (Ex. 20:4-6)

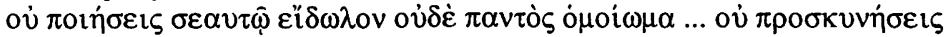

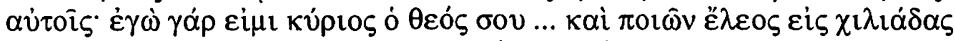

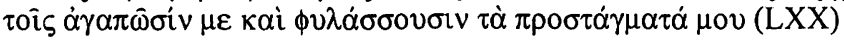

While the first commandment stands against polytheism (Philo, Qui. Div. Her. 169), the second stands against image worship in any form. Whereas the first emphasises whom to worship, the second stresses not only whom to worship but also how to worship. The worshipper who is committed to worship only Yahweh must not use shaped images, a practice common to Israel's neighbours. Positively, one should worship and serve Yahweh as he is, because Yahweh is the 'I AM' who is always present with them. Yahweh's jealousy consists in his holiness which means that no image can adequately represent him..$^{30}$ With a deep understanding of who Yahweh is, each covenant community member is commanded to worship him without external representation. The commandment is linked with God's promise to be merciful to those who love him and keep his commandments.

The nature and value of true worship are made clear in John to the Samaritans, Greeks and Jews. The verb $\pi \rho 0 \sigma \kappa v v \varepsilon i v$ appears 11 times; in 4:20-24 alone it occurs 9 times and in 9:38 and 12:20 once each. Its cognate $\pi \rho \circ \sigma \kappa v v \eta \tau \eta \dot{s}$ occurs once in plural $(4: 23)$. When the Samaritan woman raised the question of the place of worship, Jesus was quick to say that it is more important to know whom and how one should worship than to know where one needs to worship (4:20-24). He states that one should worship God by recognising him as the Father. Rather than presenting the image of an angry and jealous God far away from his people, John portrays him as an approachable Father. God is Spirit not only in the sense that he is what he is, but also that he relates to humans by his works. ${ }^{31}$ Therefore he cannot be contained in images as other religions of the Mediterranean world held. Worship happens when a person participates in the life of the Spirit and accepts the truth revealed in Christ. ${ }^{32}$ According to John, one should worship only the God who is revealed in Christ.

30 See Durham, Exodus, p. 287.

31 Cf. Brown, John I-XII, p. 172; Beasley-Murray, John, p. 62.

32 S.S. Stuart, 'A New Testament Perspective on Worship', EQ 68 (1996), 217.

On the Johannine concept of worship see further J.J. Kanagaraj, 'Worship, 
It is ironic that the Greeks who came to Jerusalem to worship Yahweh should wish to see Jesus (12:20-26). Jesus' response, referring to the Son of Man and his death, is deliberate. By this, Jesus indicates that real worship lies in seeing the glorified Son of Man in whom the glory of the Father has been revealed $(1: 14,51 ; 13: 31-32$; $17: 4,24)$. The historic event of redemption from Egyptian bondage, which the Passover primarily depicts, is fulfilled in Jesus who, as the Passover lamb, was sacrificed on the cross-an event regarded by Greeks as folly (cf. 1 Cor. 1:21-24). Without condemning the idol worship or the polytheism of the Gentiles, John positively states that worship of the one God, Yahweh, is now possible in Christ Jesus, the revelation of the invisible God. John, thus, is more positive in showing the God before whom one should bow down and serve. Interestingly enough, the idea of serving follows the statement about the glorification of the Son of Man in 12:20-26.33 That is, John does not deny that worship and service are integral parts of God's ethical demands. But he goes a step further to show the way in which these demands can be fulfilled.

The theme of worshipping God in his holiness is also implied in the narrative of Jesus cleansing the temple (2:13-22). By means of this prophetic act, John declares to the Jews of his time that the glorified body of Jesus is now the new temple in which one can worship God. However, the main hindrance to the right worship was the trading performed in the temple-court with the greedy aim of obtaining material gain. This was a form of idolatry (cf. Eph. 5:5) that prevented people from worshipping and serving Yahweh. But Jesus restored the worship of one God by sacrificing himself (cf. 2:21-22). The second commandment can be fulfilled, according to John, by believing in Christ and by following him.

It is striking that in both the second commandment and in John's Gospel love for God is expressed in terms of obeying or keeping his commandments $(14: 15,23)$. John's interest in true worship, his statement in the same context that salvation is from the Jews $(4: 22)$, and his understanding of love for God as obedience to his commands betray the author's identity as a Jew, who understood the second commandment in a positive way due to his experience with Christ.

Sacrifice and Mission: Themes Interlocked in John', Indian Journal of Theology 40 (1998), 16-39.

33 Although $\delta$ iakové $\omega$ is used rather than the $\lambda \alpha \tau \rho \varepsilon v \omega$ of the LXX, the idea is not far from the Hebrew עבד used in Ex. 20:5. 


\section{The Third Commandment}

'You shall not take the name of the Lord your God in vain; for the Lord will not hold him guiltless that takes his name in vain' (Ex. 20:7)

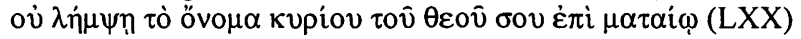

The 'Name' in biblical thought is an aspect of God's revelation and his character to his people. God revealed himself, his love and saving power, by using the names YHWH, the Lord (Ex. 3:15; 6:3-6), and ' $I$ am that I am' (Ex. 3:14). The people of Israel treated God's name as a gift, given to them to assure them of his presence in the midst of their life and worship. The author of Deuteronomy speaks of God who promised his presence at the place of his name (Dt. 12:11-12; 14:2324). He caused his name to dwell in the places of worship to enable his people to have fellowship with himself (1 Ki. 8:29-30). In Solomon's prayer, God's name is personified as the one who dwells in the temple and as the one who needs to be known and acknowledged by all peoples ( $1 \mathrm{Ki} .8)$. Thus God's name is portrayed in the Old Testament as the revelation of his character, the mark of his personal relationship with his people, redemption from bondage and of security in the midst of dangers (Pr. 18:10; Ps. 20:1, 7). The gift of God's name also implies that he wanted his people to invite him through prayer to be in their midst, both in the ordinary routine of their lives and at the time of their needs ${ }^{34}$ (cf. $1 \mathrm{Ki} .8: 33,35$ where offering prayers is connected with acknowledging his name). God's name needs to be celebrated as holy and it should not be abused or neglected (cf. Lv. 19:12). The Jews at the time of Jesus held God's name in such honour that they would not even pronounce it for fear of transgressing the commandment.

John too exhibits a similar tendency. He invests the term ôvoua with special significance. In line with the biblical concept of the name of God, he understands God's name as revealed in the Logos which should be acknowledged in faith by human beings (1:12). The incarnation of the Logos means that God has now established a new relationship with humans by dwelling in their midst. The Old Testament understanding of the dwelling of the name of God among people is now applied to the Logos-in-flesh in whom one can see the glory of God (1:14). The invisible God becomes visible and even approachable to humans by his name revealed in Jesus.

The idea of revelation is further developed by John's description of the övo $\mu \alpha$ of God and his $\delta$ ó $\xi \alpha$ as to some degree synonymous terms.

34 See Wallace, Ten Commandments, p. 55. 
Both have been granted to Jesus by the Father $(17: 11,12,22)$. By using the verb $\phi \alpha v \varepsilon \rho o ́ \omega$ with övo $\mu \alpha$ and $\delta$ ó $\xi \alpha$ as objects $(17: 6 ; 2: 11$; cf. 7:4; 9:3), John portrays the self-revelation of God. The very purpose of Jesus' mission was to reveal the name of God to the world and to continue to reveal it supremely in his sacrifice on the cross (cf. the use of $\gamma v \omega \rho i \zeta \varepsilon t v$ in 17:26 both in aorist and future) ${ }^{35}$-an idea expressed in John also by using $\delta o ́ \xi \alpha$. The name of God, which is his glory, is given to the disciples as a gift in order to fulfil the divine purpose that they all should be one (cf. 17:22 and 17:26). According to Bultmann, it makes no difference whether one says that Jesus reveals the name of God or that he reveals his own glory. ${ }^{36}$

As we observed earlier, 'I AM' sayings in John are another means for God to reveal and relate with his people. Dodd argues that the

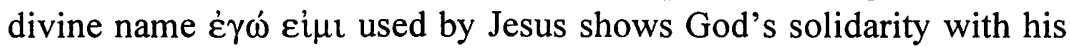
people, particularly with Christ, the representative of his people. ${ }^{37}$ John insists that prayers can be offered by acknowledging the divine name revealed in Jesus (14:13-14; 16:24). It is in the name of God that the followers of Christ would be kept from the evil of this world (17:11-12,15) —an idea similar to the Old Testament understanding of the Lord's name as the place of protection. The temple motif inherent in 1:14 and 2:19-22 is reminiscent of Solomon's temple built for the dwelling of God's name. The connection between 'holy Father' and 'his name' made in 17:11 shows that the character of God is 'holy' and therefore that it can deliver the believers from the corruption of this world $(17: 12,15)$.

It is notable that John seems to reflect the third commandment in presenting the significance of the name of God. We should also observe that he avoids the negative prohibition, 'You shall not take the name of the Lord in vain'; neither does he make any reference to the punishment that may fall on those who dishonour his name. But he puts the commandment in a positive framework and maintains that one can appreciate the sovereignty of God's name by believing in and receiving the same name now revealed in the Logos incarnate. Thus

35 See Brown, John I-XII, pp. 768, 773; F.F. Bruce, The Gospel of John (Grand Rapids: Eerdmans, 1992), p. 337.

36 Bultmann, John, p. 498. See also J.J. Kanagaraj, 'Mysticism' in the Gospel of John: An Inquiry into Its Background (JSNTS 158; Sheffield: Sheffield Academic, 1998), pp. 231-32.

37 Dodd, Interpretation, pp. 93-96, 261-62; cf. Schnackenburg, John 2, pp. 79-89, who argues that in the OT the phrase $\dot{\varepsilon} \gamma \omega$ $\varepsilon i \mu \mathrm{l}$ is used to reveal God in his divine prerogative and his relationship with his chosen ones (Gn. 28:13, 15; Ex. 3:14; Is. $43: 10-11 ; 45: 5,6,18$, etc.). See also above p. 40 and n. 28. 
he points out that Christ is the bearer of God's name and that one can really experience its power by coming into personal encounter with Christ. Such an assertive and practical treatment of God's name is inexplicable if the author was not a Jew, who was convinced that Jesus, the Messiah, is the revealer of God's name in all its glory. For him 'believing' rules out the possibility of taking the name of God in vain and leads not to punishment but to life (cf. 20:31).

\section{The Fourth Commandment}

'Remember the sabbath day, to keep it holy ...' (Ex. 20:8-11)

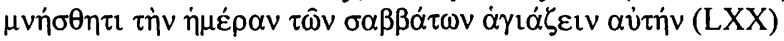

The inner meaning of the fourth commandment can be grasped by comparing the two versions of the Decalogue, in Exodus and Deuteronomy. Although both versions command the cessation of work on the seventh day, the reason given for observing the sabbath varies. The rest caused by the cessation of work does not seem merely to be a psycho-physical recreation, but, in the light of Deuteronomy 5, it is an occasion to show human love and concern.

Deuteronomy 5 emphasises the social dimension of the sabbath day in commemorating the freedom from Egyptian bondage. The people who are specifically mentioned in Deuteronomy 5 as beneficiaries of the sabbath are the socially disadvantaged, the oppressed and, above all, the slaves, both male and female. ${ }^{38}$ It was celebrated as the day of freedom from oppression and slavery. The sabbath brought relief to those who were heavily burdened. It was the day of expressing one's solidarity and fellowship with her/his family, neighbours, the underprivileged, and also with the animal world. This is the way one can express holiness on the day set apart by God.

Santification of the sabbath also involves worship by the whole creation, as the other account shows. Exodus 20 appeals to the creation story as the basis of sabbath observance. The Old Testament uses ששבת as a term denoting a day of cessation from the daily routine for religious reasons ${ }^{39}$ The right thing to do on a sabbath is to seek fellowship with God, for the goal of creation, having humanity as its head, is to offer praise to God. The priestly version of the sabbath commandment emphasises the need to express the free grace of God to all living things and to celebrate God as the creator and liberator. Lochman is right in identifying the fourth commandment as 'the

38 Cf. Lochman, Signposts, p. 61.

39 Durham, Exodus, p. 289. 
festival of freedom'-the Deuteronomic account emphasising 'freedom' and the priestly account emphasising 'festival'. ${ }^{40}$ The sabbath thus has both vertical and horizontal dimensions: on the one hand, it is the remembrance of God's creation and deliverance and, on the other, it is an opportunity to serve humanity.

As in the Synoptics, so also in John, sabbath observance becomes the subject of sharpest conflict between Jesus and his adversaries. John records two occasions which triggered conflict on sabbath ethics. Both are healing miracles. The first one is the healing of the man who had been ill for thirty-eight years (5:1-18). At first, the healed man himself is accused of breaking the sabbath rule because he was doing a work prohibited on a sabbath (i.e. carrying the pallet from one domain to another). ${ }^{41}$ But later the accusation is so sharply pointed towards Jesus that the Jews planned to kill him because he performed healing on a sabbath (5:16). The second event is the healing of a man born blind (ch. 9). 42 The synoptic idea of superiority of human beings and their needs over mere legal observance of sabbath is not missing in John. But he seems to add several other factors in conformity with the Decalogue.

(i) The healing miracles show that sabbath is the day when one can see God and experience his saving power in Jesus. The underprivileged, helpless, and those who had been kept in slavery to evil forces could experience the love and power of God revealed in Jesus. Jesus is presented as the one equal to God-something treated as blasphemy at that time. He freed people from life-long bondage, in the first case from a thirty-eight year long illness and helplessness, and in the second case from the blindness/darkness that was dominating the man even from his birth. The fourth commandment exalts God as the Lord who creates and redeems. In John's Gospel the same God acts in Jesus to recreate by giving wholeness of life to the sick (cf. 7:23) and the blind. By revealing God as deliverer and by freeing people from oppressive forces, Jesus fulfils the sabbath ethic of the Old Testament. As Barrett puts it, Jesus' act in John 5 is 'the

40 Lochman, Signposts, pp. 57-72, esp. pp. 60-61, 63.

41 The Mishnaic law (Shabbath 7:2; 10:5) prohibits thirty-nine types of work in which taking one's couch from one domain into another is included.

42 This, however, does not mean that Jesus healed people on the sabbath only twice. He could have done so many more times, as the imperfect tense $\dot{\varepsilon} \pi \circ i \varepsilon 1$ (5:16) and है $\lambda \nu \varepsilon v(5: 18)$ show. 
accomplishment of the redemptive purpose of God toward which the Law had pointed.' 43

(ii) John connects the healing miracle in ch. 5 with moral reformation and sanctification. God's merciful act to the sick man laid upon him the obligation to cease from sinning (5:14)..$^{44}$ Jesus warns that worse will happen to him if he does not stop sinning, probably pointing to the final judgment (cf. 5:29).45 If sanctification denotes turning away from evil deeds, as John 17:14-18 suggests, then the Old Testament concept of sanctification of the sabbath is stressed and also realised by the Johannine Jesus. The idea that the sabbath should be kept holy by means of bringing complete deliverance in human lives is brought out by John more than once. For John the sabbath is meant for encountering God in Christ, for being made whole and for taking the decision not to perform evil. Thus he shows that in Jesus the real meaning of the sabbath rule is fulfilled.

(iii) Sabbath observance is linked in John with worship and more particularly with the identity of Jesus. On the sabbath Jesus not only freed the man from his blindness but also accepted him when he was cast out and revealed himself as the Son of Man (9:35-37), the mediator of salvation. In this context the title Son of Man indicates that Jesus is the unique revelation of God in whom people are invited to put their trust. Carson comments that the true conflict in the healing of the blind is between the view that Jesus must be interpreted in terms of the law (as held by the Pharisees) and the view that Jesus is the self-disclosure of God by whom and through whom the deepest significance of the law can be discerned. ${ }^{46}$ The healed man's worship (9:38) indicates his perception of God in Jesus and his faith in him. The inner meaning of the sabbath is thus brought into focus. John agrees with the demand of the law that on the day of the cessation of work (sabbath) it is right to do good to the sick and to the abandoned as well as to give praise and worship due to God. But he goes a step further to say that in Jesus one can fulfil the sabbath ethics. He focuses more on what one should do on the sabbath than on what one should not do. Such a fresh look at sabbath ethics is possible for a Jewish Christian more than for anyone else.

43 Barrett, St. John, p. 321. See John 7:22-24 where Jesus' healing of the whole man becomes the fulfilment of OT circumcision.

44 Although all individual sicknesses are not directly the result of $\sin$, this particular man's suffering seems to have connection with his specific sin.

45 Carson, John, p. 246.

46 Ibid., p. 376. 


\section{The Fifth Commandment}

'Honour your father and your mother, that your days may be long in the land which the Lord your God gives you' (Ex. 20:12)

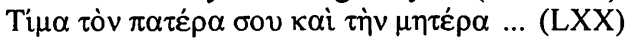

Unlike the fourth commandment, the fifth gives a promise rather than a reason for keeping it. ${ }^{47}$ The fifth commandment, according to Philo, stands on the border-line between the human and the divine (Spec. Leg. 224). James Bergquist maintains that the fifth commandment is 'the first step toward making the home a place of shared life and responsibility. ${ }^{38}$ The immediate sphere in which one can express the life of God is her/his own home. The Piel imperative singular of כבד used for 'to honour' means 'to give weight to', 'glorify', 'esteem' in the sense of giving precedence and importance. ${ }^{49}$ The parallel verse in Leviticus 19:3, which puts mother before father, uses the verb.רי with the meaning 'have reverence for, stand in awe of'.$^{50}$ This means that according to the fifth commandment, parents are to be treated with high esteem. They are not to be devalued in family relationships and their views are to be taken seriously. It is to be noted that in a male-dominated Jewish society women attain exceptional importance in this commandment. Boecker points out that although the woman's position in law was in many ways very limited, as mother she was equal to the man as father and had full claim on the obedience of the children (cf. Dt. 21:18-21 which speaks of both the father and mother who together discipline their disobedient son). ${ }^{51}$

Does the same picture emerge also in John's Gospel? The synoptic words, 'Who are my mother and my brothers? ... Whoever does the will of God is my brother, and sister, and mother.' (Mk. 3:33-34 par.) are not found in John. John does not comment, as Luke does, that Jesus was obedient to his parents (Lk. 2:51). However, throughout the Gospel he gives importance to the filial relationship between Jesus and his heavenly Father and at least in two important events (i.e. the wedding at Cana and the crucifixion) he shows Jesus honouring his mother.

In the wedding episode Jesus' reply to the indirect request of his mother for wine, 'O woman, what have you to do with me ( $\tau$ ' $\dot{\varepsilon} \mu \mathrm{r}$

47 G. von Rad, Deuteronomy, p. 58 (cf. Eph 6.2f.).

48 Bergquist, Ten Commandments, p. 70.

49 See Durham, Exodus, p. 291; Lochman, Signposts, p. 81.

50 Durham, Exodus, p. 291.

51 As shown by Stamm and Andrew, Ten Commandments, p. 96. 


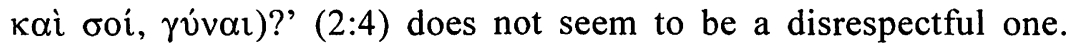
Brown observes that the term rúval used for 'mother' is not a rebuke, nor an impolite term, nor an indication of a lack of affection (cf. 19:26). ${ }^{52}$ In fact Mary is called the 'mother of Jesus' four times in vv. $1-12$, twice after Jesus had addressed her as rvival. Even the question, 'What have you to do with me?', does not question her claim as a mother; neither does it reflect the refusal of her role in Jesus' ministry. ${ }^{53}$ The expression only indicates that although Jesus is willing to comply with his mother's request, he was looking for the 'hour' of his Father. For he, as the Son of God, did nothing of his own accord, but only what he has seen the Father doing $(5: 19)$. The ${ }^{\circ} \rho \alpha$, which refers to the hour of revealing his glory through a miracle, and which points forward to the supreme moment of his revelation on the cross, is not in Jesus' control, but in that of the Father. ${ }^{54}$ In Jewish tradition, as Rupert of Deutz observes, it is no disrespect to a father or mother when their son seeks to honour God more than his parents by doing God's work. ${ }^{55}$ Jesus honoured his mother by obeying her within the framework of his complete obedience to his Father. By revealing his glory in the wedding, Jesus indeed revealed his Father's glory and at the same time honoured his mother by fulfilling her request. John's Gospel as a whole bears witness to the fact that the purpose of Jesus' mission was to honour/glorify the Father $(4: 34 ; 8: 49$ where $\tau \mu \alpha \hat{\alpha} v$ is used; $13: 31-32 ; 17: 4)$. Jesus' act of honouring his Father and mother is the fulfilment of the fifth commandment and he expects human beings similarly to honour God through His Son (5:23: 'That all may honour the Son, even as they honour the Father. He who does not honour the Son does not honour the Father who sent him.'). This can be done by 'abiding in' him (15:8).

52 Brown, John I-XII, p. 99; cf. also Barrett, St. John, p. 191. John McHugh, The Mother of Jesus in the New Testament (New York: Doubleday, 1975), p. 363, argues that in the light of Jesus using the same term to address other women (Jn. 4:21; 8:10; 20:13; Mt. 15:28; Lk. 13:12), it was a normal form of courteous address to someone outside the family and that thus Jesus was drawing attention away from Mary's blood-relationship with him by addressing her as $\gamma v$ val. However, the same word that was used at Calvary to show care and affection can be accounted only as the mother who gave him birth. His conjecture that on the cross Jesus perhaps was thinking of something other than physical ties of blood has no basis. See Josephus, Antiquities 17.74 where the word 'woman' is used as a mark of affection.

53 Beasley-Murray, John, p. 349, citing Brown.

54 Cf. Brown, John I-XII, p. 100.

55 Cited in McHugh, Mother of Jesus, p. 369. 
The act of honouring the mother and the Father reaches its climax in Jesus' death on the cross. While his passion and death constitute the supreme hour of honouring the Father, because in this the Son expresses his complete obedience to the Father, the same passion and death becomes in John also the supreme hour of honouring his mother. The first utterance of Jesus from the cross that John records ('Woman, behold, your son!' and to the beloved disciple, 'Behold, your mother!' 19:26-27) does not imply that the disciple came under the care of Mary, as the Roman Catholic interpretation suggests. The evangelist's comment in 19:27b ('And from that hour the disciple

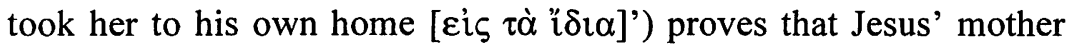
was placed by Jesus under the protection and care of the beloved disciple. ${ }^{56}$ The disciple here takes over the rights and duties of a grown son as regards Mary rather than Mary receiving such a duty. 57 Stauffer observes that Jesus exercises from the cross the right of the son mentioned in the old Jewish law and, in my view, this law is rooted in the fifth commandment. ${ }^{58}$ That this right is passed on from Jesus to one of his disciples shows that honouring one's parents is an expression of Christian ethics.

\section{The Sixth Commandment}

'You shall not kill' (Ex. 20:13)

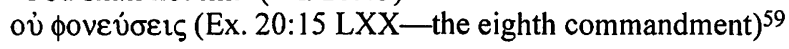

The sixth commandment also indicates Yahweh's expectation of those who would enter into covenant with him. The Hebrew verb רצח ('kill', 'slay') primarily refers to the killing or taking away the life of a fellow-member of the covenant community (cf. Ex. 21:12; Nu. $35: 30$ ) rather than to killing in war, to capital punishment, or to the killing of animals. Thus the killing of a human within the covenant community (Ho. 4:2; Je. 7:9) for whatever cause, under whatever circumstances and by whatever method, is prohibited. ${ }^{60}$ This is the

56 Bultmann, John, p. 673 , thinks that this scene undoubtedly has a symbolic meaning. However, Dodd rejects any symbolising of the scene, Interpretation, $\mathrm{p}$. 428, n. 2.

57 So A. Dauer, Die Passionsgeschichtliche im Johannesevangelium: Eine traditionsgeschichtliche und theologische Untersuchung zu Joh 18,1-19,30 (Munich: Kosel, 1972), pp. 322-26; as cited by Beasley-Murray, John, p. 350.

58 Ibid., p. 349.

59 Philo counts it as the seventh commandment.

60 Durham, Exodus, p. 293. 
ethical norm of Yahweh given to those who have committed themselves to him.

The Fourth Evangelist treats murder directly as an act of the

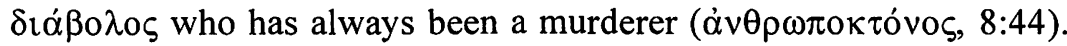
The Johannine Jesus prohibits killing by saying that the descendants of Abraham do not follow such an immoral code (8:37: 'I know that you are descendants of Abraham; yet you seek to kill [ả $\pi 0 \kappa \tau \varepsilon i ̂ v \alpha l]$ me'; cf. 8:40). Killing a human being is a sin and in fact a slavery to $\sin (8: 34,37)$. Among the four evangelists, John, like Matthew, has Jesus strongly condemning Peter for striking the high priest's slave with a sword (18:10-11; cf. Mt. 26:52-54). In the whole trial narrative, and afterwards in the event of crucifixion, John consistently states that Jesus' kingship, which is the expression of God's sovereignty, is not to be won by violence or by declaring war (cf. 18:36).

Apart from these direct references which prohibit killing another human being, John takes up strongly a positive approach in presenting the sixth commandment. The Johannine community believed that the one who does not love another member in the community has hatred which is equivalent to murder $(1 \mathrm{Jn} .3: 11-12$, where $\sigma \phi \alpha \dot{\zeta} \varepsilon ı v$ is used

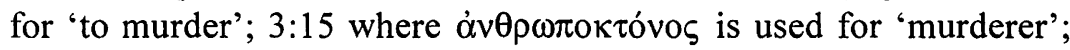
cf. Mt. 5:21-26). John reflects this idea when he contrasts hatred and love. He does not plainly say, 'Do not kill', but he strongly emphasises the positive dimension of this ethical code through the

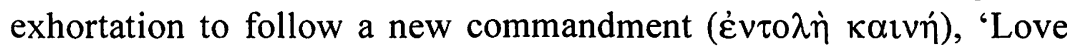
one another' $(13: 34 ; 15: 12)$. One should love the fellow-beings even to the extent of laying down one's life for them (15:13). The depth of love which the Johannine Jesus demands from his followers makes the murderous act fully impossible to commit. John thus brings out the positive significance of the sixth commandment by expressing it in a more redemptive and positive manner.

Love comes from God who himself is love ( $1 \mathrm{Jn} .4: 16)$. God loved the world in order to save it from darkness (death) and to give the heavenly life $(3: 16)$, even though it constantly hates him and his envoy, Jesus Christ (7:7). Jesus loved his followers both individually and collectively even to the extent of laying down his life for his own (13:1; cf. 11:5, 36; 10:11, 15, 17-18). His love embraces people who do not belong to his circle as well (10:16- $\alpha \lambda \lambda \lambda \alpha \pi \rho$ ó $\beta \alpha \tau \alpha$ है $\chi \omega)$. The Christians' love for one another, says John, should be grounded in such love: the love of God for his Son as well as for the hating world and the love of Jesus for his followers $(13: 34 ; 17: 23)$. Norman Geisler quotes John 15:13 ('No one has greater love than this, to lay down 
one's life for one's friends.') as the biblical principle of charity, for example, for organ plantation. According to him, to give one's eye, lung or kidney to someone who has none, while we are alive rather than after we die, is the highest form of sacrifice one can ever render to one's fellow-being. ${ }^{61}$ For John love is not merely an abstract entity or vacuous feeling, but it is an outward expression of specific commandments (cf. 14:15). Love, then, has both vertical and horizontal dimensions: it is expressed in obedience to Jesus' words (14:23) and in humble service to the needy (cf. ch. 13). By her constant witness to the world, the Church is instructed to draw people into this circle of mutual love and service. ${ }^{62}$ Even though the command to love one another even to the extent of laying down one's life for the other seems on the surface to be practised within a closed community, in view of the Church's mission to the world, modelling Jesus' mission, we should understand that John's ethical vision of love goes beyond his own community to include also those outside. For a disciple who shares in Jesus' life and mission, as Hays rightly observes, can hardly be indifferent to the needs of the world and thus the call to lay down one's life has broader implications in John as much as in the whole of the New Testament. ${ }^{63}$ In brief, John insists on giving one's life for the sake of others instead of taking away another person's life or even one's own.

\section{The Seventh Commandment}

'You shall not commit adultery' (Ex. 20:14)

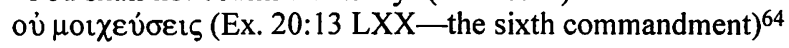

Within the Old Testament (Gn. 20:9; 39.9; Ex. 32:21, 30, 31; 2 Ki. 17:21) adultery is mentioned as 'the great sin'. The Hebrew word for 'to commit adultery' is used with both men and women as subject, more frequently of men. ${ }^{65}$ Thus the seventh commandment prohibits sexual intercourse of a man or of a woman with a member of the opposite sex, whether married or engaged or single, to whom she/he is not married (Lv. 18:20; 20:10; Dt. 22:22-30; Ezk. 16:32; Ho. 4:13). Adultery is spoken of in the Old Testament as equivalent to idol

61 N. Geisler, Christian Ethics: Options and Issues (Leicester, Apollos, 1989), pp. 184-85.

62 Cf. R. Bultmann, Theology of the New Testament 2 (London: SCM, 1955),

p. 82; Sanders, Ethics in the New Testament, p. 36.

63 Hays, Moral Vision, p. 145.

64 Philo treats this as the sixth commandment.

65 Durham, Exodus, p. 293. 
worship, the violation of the bond of covenant relationship with Yahweh. The penalty for adultery was to be stoned to death (Dt. 22:24) or occasionally death by burning (Gn. 38:24; Lv. 20:14; $21: 9$ ).

Adultery is also condemned in John's Gospel. Among the four evangelists, only John records Jesus' conversation with an adulterous woman in Samaria (Jn. 4). By unveiling the number of husbands that the woman had, Jesus shows that it is wrong to have more than one spouse. This is reiterated in Jesus' use of singular $\alpha v \eta \dot{p}$ in his words,

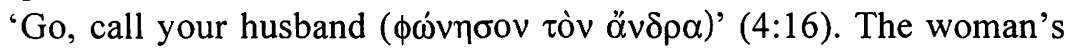

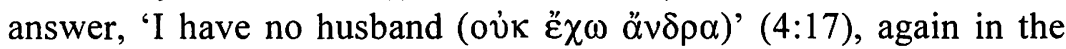
singular, acknowledges her failure to follow the ethical demand. The exchange suggests that Jesus expected monogamy as a norm of human life and that in case of failure he demanded a transformation in life. He eventually leads the adulterous woman into a new life-a life now approved by God and transparent to her community. John allocates almost one full chapter to show how Jesus, disapproving of adultery, took a redemptive and positive approach towards an adulterous woman to bring her to a life of witness and human dignity.

John shows in a different way from the Synoptists that Jesus preserved the sanctity of the marriage. By recording the wedding at Cana even at the early stage of Jesus' ministry, John demonstrates how Jesus chose such an occasion to perform his first miracle and thereby to manifest his glory $(2: 11)$.

\section{The Eighth Commandment}

'You shall not steal' (Ex. 20:15)

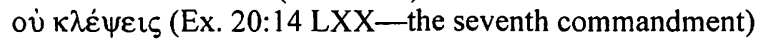

The Hebrew word גנב used here means 'stealing in secret or by duplicity' 66 and depicts stealing of any kind, including stealing human beings, and under any circumstances. By not stealing, the covenant people are expected to protect the basic rights of all humankind. The eighth commandment requires a positive attitude of love and helpfulness toward one's neighbours and their possessions. Any damage done to people and their property can be treated as stealing. Substantially this commandment is the same as the tenth commandment: 'You shall not covet', the root cause of stealing. It seeks to protect human rights to live free from abduction, violence, threats, economic oppression, and exploitations. ${ }^{67}$ Philo includes in

66 Durham, Exodus, p. 295.

67 See Lochman, Signposts, pp. 131-32. 
the list of stealing defaulting debtors, repudiations of deposits, and partnerships which are not true to their name (Decal. 171).

For John all property belongs to God, because God created all things through the Logos (1:3). Does John exhort not to steal? There are at least two Johannine narratives which take up the theme of stealing. Among the four evangelists John alone describes Judas

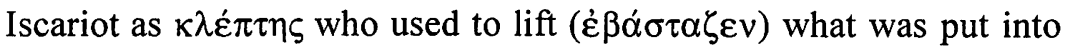

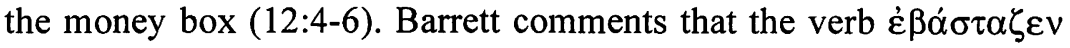
here primarily means 'to carry away' or 'to pilfer' ${ }^{68}$ The word $\kappa \lambda \varepsilon ́ \pi \tau \eta \zeta$ shows him as the one who had lust for money and who used to snatch away what belongs to others and spend it for his own end. Judas' pseudo-concern for the poor by specifying 'three hundred denarii' makes it probable, as Carson suggests, that he expected that amount to come into his money box so that he could draw some for himself ${ }^{69}$ The negative picture of Judas Iscariot which John paints (cf. 13:27 which refers to the entry of Satan into Judas; and 13:30 which symbolically indicates the darkness into which he went) in this context implies that all the works of Judas, including stealing, are wrong.

Stealing, robbing, killing, and destroying are presented by John in parallel terms. This is evident in Jesus' discourse on the Good Shepherd where he compares himself, as the good shepherd, with the hirelings (10:1-10). These hirelings are described as those who steal sheep and kill them. The very characteristic of the thief is to steal ( $\kappa \lambda \dot{\varepsilon} \pi \tau \omega)$, to kill/slaughter $(\theta \dot{v} \omega)$, and to destroy ( $\dot{\alpha} \pi$ ó $\lambda \lambda v \mu \mathrm{l}, 10: 10)$. The term $\tau \dot{\alpha} \pi \rho{ }^{\prime} \beta \alpha \tau \alpha$ is used here, as it is in the Old Testament, as an image to denote the people of God who obey the voice of Jesus and follow him (10:3-5). If so, the stealing that is mentioned here implies the attempt to lift people away from the path of obedience to Christ possibly by offering wrong teaching and theology. Those who practise this are called by Paul 'fierce wolves' who will draw away the disciples after them by speaking perverse things (Ac. 20:29, 30). This eventually leads the flock to lose the life God has designed for them. In contrast, Jesus lays down his life for the welfare of the sheep. God, out of His love, has given His only Son for the salvation of humankind (3:16-18) and the greatest form of love is to lay down one's life for the friends (15:13). Thus Jesus not only condemns stealing of all kinds, but also shows in his person how to fulfil the

68 Barrett, St. John, p. 413.

69 See Carson, John, p. 429. 
eighth commandment. He defines the commandment in a more positive and redemptive manner. In John 'giving' and 'loving' replace stealing, robbing, and destroying. Any efforts to fulfil the eighth commandment other than by giving and laying down one's own lifeinterests will end up in legalism and failure. The evangelist's comment on 'giving to the poor' $(13: 29 \mathrm{~b})$ and Judas' remark to give the cost of the ointment to the poor (12:5) endorse the fact that Jesus expected his disciples to give alms to the poor and to share the resources with one another in the community. The pragmatic side of the commandment 'Love one another' calls for economic justice, as 1 John 3:16-18 shows, that is, to provide help to those who need a livelihood. ${ }^{70}$ Only by giving can one fulfil the commandment, 'You shall not steal'. John sees Jesus, as the one who gave himself fully for others, as the ultimate fulfilment of this commandment.

\section{The Ninth Commandment}

'You shall not bear false witness against your neighbour.' (Ex. 20:16)

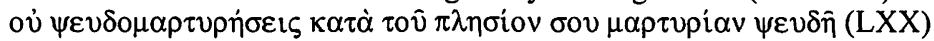

In the light of the Old Testament references (Dt. 19:18; Ps. 27:12; Pr.

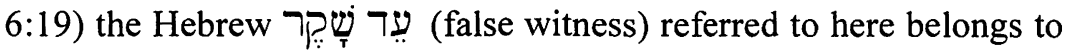
a judicial context. Jan Lochman suggests that it implies an emergency situation of establishing the truth in which someone's testimony will determine either the acquittal or condemnation of the accused.71 However, he goes on to say that the ninth commandment cannot be restricted to the court-room situation alone; for him it also refers to our everyday life situation in which we often face accusation, prosecution and punishment. ${ }^{72}$ This is confirmed by the Deuteronomic version of the ninth commandment. The word שָ used in Deuteronomy 5:20 means 'emptiness, worthlessness', referring to a 'base witness' or to any worthless testimony in our daily life..$^{73}$ The word רֵ which means 'companion, neighbour, friend, fellow-citizen' refers in the Old Testament to a person with whom one stands in a reciprocal relationship and in legal contexts, to a fellow-member of the covenant community. ${ }^{74}$ The ninth commandment, then, states

70 See Hays, Moral Vision, p. 145, who focuses on the image of the Community to describe the ethical vision of the New Testament at large, and of the Gospel and the Epistles of John in particular.

71 Lochman, Signposts, p. 136.

72 Ibid., p. 137.

73 Cf. Nielsen, Ten Commandments, pp. 91-92; Durham, Exodus, p. 296.

74 Durham, Exodus, 296. 
positively that justice and truthfulness should be maintained in any community that commits itself to the covenant-relationship with God. A lie or a false witness strikes at the very root of human co-existence in marriage, family, church and society. ${ }^{75}$ Christian ethics call for truth, both in speech and practice, for a healthy relationship with one another.

Where can one find truth? How can it be practised in a world of falsehood and corruption? The Fourth Evangelist yields answers to these questions. He nowhere says, 'You shall not bear false witness against your neighbour', but a careful reader of the Fourth Gospel can see the spirit of this commandment behind the oft-repeated references to $\mu \alpha \rho \tau v \rho i \alpha$ and $\dot{\alpha} \lambda \dot{\eta} \theta \varepsilon \imath \alpha$ and their cognate words. Instead of $\psi \varepsilon v \delta o \mu \alpha \rho \tau v \rho i \alpha$ John insists on $\mu \alpha \rho \tau v \rho i \alpha$, and in sharp contrast to falsehood he sets $\dot{\alpha} \lambda \dot{\eta} \theta \varepsilon \imath \alpha$ coupled with $\chi \alpha \dot{\alpha} \rho \iota$. The fullness of grace and truth is found in the Logos incarnate, the Son of God. He became accessible to human beings so that they can experience truth and emulate him. God who sent the Son into the world is true ( $\dot{\alpha} \lambda \eta \theta \dot{\eta} s)$ and the Son speaks the things he heard from Him (8:26) and therefore what he speaks is true and authentic. The very purpose of the Son to come into the world is to bear witness to the truth. Jesus' statement, 'Every one $(\pi \hat{\alpha} \varsigma)$ who is of truth hears my voice' (18:37) shows that he expects people to emulate him by obeying his words. When John speaks of obedience to Jesus' commandments, he introduces the Spirit of Truth $(14: 15,17)$ who will guide the believers into all truth $(16: 13)$. In other words, Christ did not come to give a witness of falsehood, but to witness to the truth and his witness is genuine. There is only one

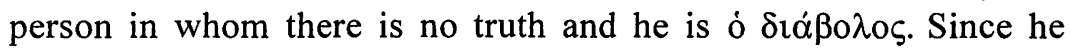
speaks lies ( $\tau$ ò $\psi \varepsilon \hat{v} \delta o \zeta)$, rather than truth, by nature he is a liar

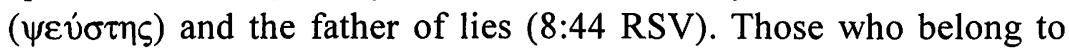
him bear false witness in every day life. In contrast, Jesus speaks truth and calls people to believe in him (8:45-46). He embodies in himself the divine truth, which means life for believers, and so becomes the way for all who seek salvation (14:6). ${ }^{76}$

The Hebrew term spor for $\dot{\alpha} \lambda \dot{\eta} \theta \varepsilon \iota \alpha$ denotes God's trustworthiness, reliability, and, above all, the demonstration of fidelity between persons. ${ }^{77}$ Many commentators expound the meaning of $\alpha \lambda \dot{\eta} \theta \varepsilon \imath \alpha$ along similar lines, but they combine it with $\chi \alpha$ óp $\varsigma$ and bring out the

75 See Lochman, Signposts, p. 143.

76 Schnackenburg, St. John 2, p. 228.

77 See Lochman, Signposts, pp. 142-43. 
revelatory nature of God in his truthfulness. ${ }^{78}$ At any rate, the word is concerned with God's relationship with human beings. It is also concerned with co-humanity, the core relationship with one another in a community. For in John truth becomes the norm which governs human lives; human beings must 'do the truth' by practising love in daily life $(3: 21 ; 1 \mathrm{Jn} .1: 6 ; 3: 18){ }^{79}$. Those who accept the truth in Christ are sanctified by it $(17: 17 \mathrm{a}, 19)$; it becomes the reality and power in them (1 Jn. 1:8;2:4) and frees them from $\sin (8: 32-36)$.

Thus John presents Jesus as the embodiment of God's truth and hence as the one who could fulfil the ninth commandment in his mission in the world. Those who believe in him and obey him will be sanctified from falsehood. They are given the grace to live in love and unity with their neighbours. This means, they are enabled to respect their fellow-members in the society and to uphold human values and dignity. It is beyond doubt that John takes up a highly positive and redemptive approach in his ethical teachings. His ethics are thoroughly the ethics of grace that demand in response only faith that is expressed in doing the truth.

\section{The Tenth Commandment}

'You shall not covet ... anything that is your neighbour's.' (Ex. 20:17)

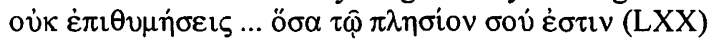

Like the ninth commandment, the tenth is also directed specifically to relationship within the covenant community. The word חמר, 'covet', describes a mental and emotional process interior to a person; it refers to an obsessive covetousness that could be the gateway to the violation of every other commandment in the Decalogue and therefore Durham identifies the tenth commandment as a kind of 'summary commandment'. ${ }^{80}$ It challenges humanity not simply about our outward acts but also about our inner thoughts and motives. ${ }^{81}$ Has John anything to say on this all-inclusive commandment? What are the factors, if any, that bind together all ethical teaching in John?

No doubt, John denounces covetousness. As a thief, Judas Iscariot coveted three hundred denarii and hence chided when Mary poured

78 See, for instance, Barrett, St. John, p. 167; Bultmann, John, pp. 73-74; Carson, John, p. 129; Beasley-Murray, John, pp. 14-15; Brown, John I-XII, p. 499.

79 See Schnackenburg, St. John 2, p. 229.

80 Durham, Exodus, p. 298.

81 See Wallace, Ten Commandments, p. 173-74. Jesus also appealed to the inner motives and thoughts in the Sermon on the Mount as basics to fulfill the Law, particularly the ten commandments. 
out at Jesus' feet the costly ointment (12:3-5). John divulges the inner motive of Judas by stating that his real concern was not for the poor but for money (12:6). Some Jewish authorities coveted the praise $\left(\delta \delta^{\prime} \xi \alpha\right)$ of the people rather than that from God and therefore did not openly confess Jesus as the Christ (12:42-43; 5:44). In contrast, Jesus did not covet the glory that may come from human beings (5:41).82 Coveting money, praise and fame which are due to others is viewed as the very characteristic of the enemies of Jesus and hence it is not to be entertained among his followers.

Apart from these references against covetousness, John appeals positively and redemptively to the deep thoughts and inner attitude of human beings. His interest in the deeper meaning of terms has been pointed out by Johannine scholars (e.g. the use of signs, symbols, irony, etc.). ${ }^{83}$ T.L. Brodie, for example, observes that through its many forms of contradiction-including shocks, style changes, obscurities, riddles and breaks-John invites the readers to move beyond superficiality and to grasp the deeper level of meaning of some of his words and concepts. ${ }^{84}$ One of the purposes of accommodating deeper level of meaning may be to challenge and change the inner attitude and thought-forms of his readers. This will enable them to have a spiritual rather than a legal perception of the ethical demands of God.

Apart from this, the idea of 'believing' in the Gospel of John touches the inner thoughts and motives of the world that is against God and His words. According to Schnackenburg, 'faith' in John appears as 'a fundamental and comprehensive decision and attitude towards the eschatological envoy of God and his saving revelation. ${ }^{85}$ That is, Johannine believing denotes 'a personal allegiance to Jesus Christ, a dedication of oneself', for $\pi l \sigma \tau \varepsilon v i \varepsilon v$ followed by $\varepsilon$ i $\zeta$ has exclusively Jesus Christ as the object of faith (only 14:1 has God as the object of faith). ${ }^{86}$ It means 'receiving' him (1:12), 'coming' to him, making commitment to him (6:35-40), and obeying him (3:36). It refers to a deep communion with Christ and thereby with God.

\footnotetext{
82 It is also possible that the Pharisees coveted the fame Jesus had during his ministry when they made an exaggerated statement, 'You see that you can do nothing; look, the world has gone after him' (12:19).

83 On this subject see Kanagaraj, 'Mysticism' in the Gospel of John, pp. 301-317.

84 T.L. Brodie, The Gospel According to John (New York: OUP, 1993), p. 19.

85 Schnackenburg, St. John 1, p. 558. Cf. above, pp. 34-35.

86 Ibid., p. 560.
} 
The idea of personal union with Christ is also conveyed by such terms as 'knowing', 'abiding in', 'hearing', 'keeping the commandments', etc. John accepts 'believing' in Jesus Christ as essential to keep the new commandment: love one another (cf. $1 \mathrm{Jn} .3: 23$ ). Schnackenburg rightly asserts, 'Faith and love sum up for John all the demands imposed on the disciple of Christ. ${ }^{87}$ There is no wonder, then, that for John unbelief is the sum-total of all sin (cf. $3: 18 ; 16: 8-9)$. Covetousness, the interior evil in human heart, can be overcome only by faith-commitment to Christ. As the tenth commandment is the heart of God's demand upon the whole of human life, so also the concept of 'believing' in John. The tenth commandment and John's idea of faith and love challenge humankind not simply on their outward behaviour, but also on the inner motives of their hearts. Whereas the commandment poses a problem in human life, John's presentation of faith and love seems to offer the solution to that problem. In other words, the commandments that were given by Moses pointed to human failure, whereas love and faith, representing the grace and truth that came through Jesus Christ, render the energising power to fulfil them. Following the radical teaching of Jesus the Jew in the Sermon on the Mount, John, as a Jewish Christian, freely reinterprets the commandment on covetousness and appeals to the inner motive of human behaviour.

\section{Conclusions}

Our investigation, in contrast to the studies hitherto undertaken on Johannine ethics, shows that the ethical aspects seem to be spread throughout the Fourth Gospel. John, the author of the Gospel, stresses love, obedience to God's words, humility and service to the needy as right things to do. Indeed the love command dominates his ethics. However, the Johannine Jesus uses the term $\dot{\varepsilon} v \tau o \lambda \eta \dot{~ b o t h ~ i n ~ s i n g u l a r ~}$ and plural and it is possible that the plural $\dot{\varepsilon} v \tau o \lambda \alpha i$ implies the individual components of the Law. In the light of the oneness motif that is prevalent in John, one can say that Jesus' $\dot{\varepsilon} v \tau \lambda \alpha i$ are God's $\dot{\varepsilon} v \tau 0 \lambda \alpha$. The early Christians, based on Jesus tradition, believed that love is the summary of the Law, particularly of the Decalogue (cf. Rom. 13:8-10).

87 Ibid., p. 559. 
Our reading of the Fourth Gospel against the background of the Decalogue indicates that John displays his knowledge of the Law expressed in the Decalogue. It also makes it clear that the Gospel of John contains enriching categories of Christian ethics most of which can be seen in other pages of the New Testament as well. The prohibition imposed on killing, committing adultery, stealing and speaking lies and coveting is, no doubt, common to all religious beliefs and practices. However, what distinguishes John from other New Testament writers is his careful display of monotheistic faith, love for God in terms of obeying his commandments, the revelation of God's name in Christ and of the fulfilment of the Jewish Law concerning the obligation to one's mother and father. However, it does not seem that he has a consistent and coherent presentation of the Decalogue in his Gospel. But wherever his narratives and discourses require, he does echo the Ten Commandments individually. Such a narrative style is an evidence of the positive approach that John takes in his presentation of the Gospel. We have seen how John reinterprets the Decalogue in its positive, redemptive and practical dimension. He presents it in unspoken language so that his readers who have 'spiritual sight' could grasp it spiritually on their own. John's literary art of communicating the truth in silence may be perceived in his use of certain words and concepts with a double meaning: superficial and deeper levels. Therefore the presence of the Decalogue and its reinterpretation in John can hardly be discarded as unintentional or unforeseen.

The author's familiarity with the Decalogue betrays his Jewish background and his belief in the abiding validity of the Law in which he had been nurtured from his childhood. His new insight in the Law, as already hinted in the Prologue (Jn. 1:17), is certainly due to his new experience with Jesus Christ. In his encounter with Christ, John realised that while Christ alone fulfils the ethical demands of God, he also offers gracious help to human beings to fulfil such demands. With this conviction, John, a Jewish Christian, proclaims the enabling power of Jesus, the Christ, to the people of his time. Biblical scholarship has recognised the close connection that exists between ethics and theology as a distinctive feature of biblical ethics, because who God is in his character, and what he expresses in his revelation, defines what is right. But in John one can see a close connection between ethics and christology, for it is in Christ that the character of God is revealed and that people can clearly see what the right things are and how to do them. 